CATALLAXY

Volume 2 Issue 2 December 2017

e-ISSN 2544-090X

¿ www.catallaxy.pl

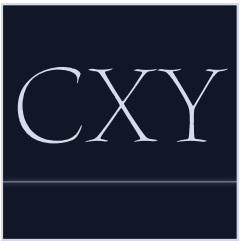

Oryginalny artykut naukowy

otrzymano: 01.11.2017 / zaakceptowano: 01.12.2017 / opublikowano online: 31.12.2017

Zygadlewicz, M. (2017). Prywatyzacja branży telekomunikacyjnej w Polsce a pozycja konkurencyjna Grupy Orange. Catallaxy, 2(2): 83-104. doi:10.24136/cxy:2i2.3.

\title{
Prywatyzacja branży telekomunikacyjnej w Polsce a pozycja konkurencyjna Grupy Orange
}

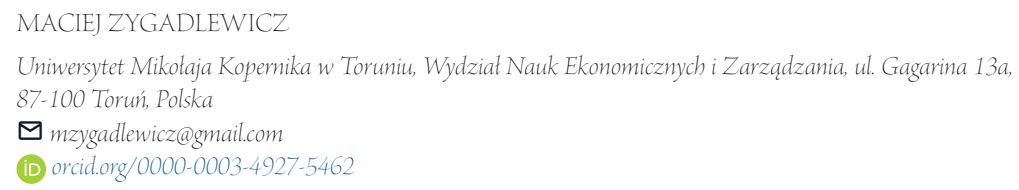

\section{Abstrakt}

Motywacja: Branża telekomunikacyjna w Polsce przez wiele lat była ustawowo zmonopolizowana przez jednego, państwowego operatora, jakim była Telekomunikacja Polska SA (dalej TP SA). W 1998 roku rozpoczął się jednak długi proces prywatyzacji spółki, któremu towarzyszyła liberalizacja branży telekomunikacyjnej. Ustugi stawały się coraz tańsze dla konsumentów, zaczęto stosować oferty konwergentne, jak również nastąpil szybki rozwój nowych technologii telekomunikacyjnych. Rozpoczęcie działalności przez nowych operatorów znacznie osłabiło pozycję konkurencyjną byłego monopolisty branży telekomunikacyjnej. W literaturze przedmiotu brakuje interpretacji gtębokich przemian dokonujących się w branży telekomunikacyjnej. Ocena tych przekształceń w aspekcie pozycji konkurencyjnej Grupy Kapitałowej Orange Polska (dalej Grupa Orange) jest głównym motywem wyboru tematu niniejszego artykułu. Cel: Celem niniejszego artykułu jest wykazanie zależności między prywatyzacją TP SA a pozycją konkurencyjną Grupy Orange. Badanie zostało przeprowadzone za pomocą oceny danych statystycznych. Analizie zostały poddane raporty Urzędu Komunikacji Elektronicznej (UKE) o stanie rynku telekomunikacyjnego w Polsce.

Wyniki: Przeprowadzona analiza wykazała zależności między zakończonym procesem prywatyzacji TP SA a pozycją konkurencyjną Grupy Orange. W wyniku tych przemian Grupa Orange straciła część udziałów na poszczególnych rynkach telekomunikacyjnych $w$ Polsce.

Stowa kluczowe: prywatyzacja TP SA; liberalizacja branży telekomunikacyjne; pozycja konkurencyjna; Grupa Kapitatowa Orange Polska

JEL:DO0; G00; B52

1. Wprowadzenie

Celem niniejszego artykułu jest wykazanie zależności między prywatyzacją Telekomunikacji Polskiej SA (dalej TP SA) a pozycją konkurencyjną Grupy Kapitałowej Orange Polska (dalej Grupa Orange).

Zakres czasowy artykułu obejmuje lata 2011-2016. Wybór ten podyktowany jest faktem, że w 2010 roku zostały sprzedane na Giełdzie Papierów Wartościowych (GPW) ostatnie 4,15\% akcji TP SA należących do Skarbu Państwa. Rok 2011 był zatem pierwszym rokiem, w którym TP SA funkcjonowała jako w pełni prywatne przedsiębiorstwo. W przypadku opisu procesu prywatyzacji, zakres czasowy artykułu został poszerzony o lata 1998-2010. 
W Sekcji 1. opisany został proces prywatyzacji w branży telekomunikacyjnej w Polsce w latach 1998-2010. Została przedstawiona charakterystyka usług telekomunikacyjnych, został także ukazany monopol TP SA $\mathrm{w}$ branży telekomunikacyjnej w Polsce, a następnie został zaprezentowany proces jej liberalizacji. W Sekcji 2. dokonany został przegląd literatury przedmiotu. W Sekcji 3. zawarty został opis wykorzystanych metod. W Sekcji 4. została opisana sytuacja $\mathrm{w}$ branży telekomunikacyjnej w Polsce w latach 2011-2015. Została przybliżona specyfika poszczególnych rynków usług telekomunikacyjnych oraz została przedstawiona pozycja Grupy Orange na każdym z nich. W Sekcji 5. zostało zawarte podsumowanie przeprowadzonej analizy.

\subsection{Charakterystyka usług telekomunikacyjnych}

Telekomunikacja jest bardzo szerokim pojęciem zawierającym $\mathrm{w}$ sobie wiele różnych usług, a w miarę upływu czasu coraz szerszym, w związku z bardzo dużym rozwojem technologii $w$ tej dziedzinie. Występują zatem różne metody klasyfikacji i podziału telekomunikacji. Kluczowym, z punktu widzenia Grupy Orange, jest podział usług w oparciu o sieć, bowiem jest on stosowany $\mathrm{w}$ raportach rocznych Grupy Orange przy zestawieniu przychodów. Wyróżnia się usługi (Babis i Czaplewski, 2011, s. 195):

1. stacjonarne - są to usługi oparte o sieci stacjonarne, które zawierają przede wszystkim usługi:

- telefonii głosowej;

- dodane do telefonii głosowej;

- informacyjne dotyczące spisu abonentów;

- dzierżawy łączy;

- transmisji danych;

- dodane do transmisji danych;

- w zakresie zarządzania siecią;

- technicznego utrzymania sieci;

2. mobilne - są to usługi oferowane na bazie sieci radiokomunikacyjnych takie, jak:

- usługi wąskopasmowe pozwalające na przesyłanie głosu, danych i faksów;

- szerokopasmowe usługi transmisji danych;

- wiadomości SMS;
- usługi dodane;

- roaming międzynarodowy;

- usługi błyskawicznego odbierania poczty elektronicznej;

- wideokonferencji;

- aplikacji czasu rzeczywistego;

- połączenia z modemami stacjonarnymi;

- możliwości ciągłego korzystania z poczty elektronicznej;

- dostępu do Internetu;

- stosowania monitoringu;

- dokonywania usług transakcyjnych, w tym również bankowych.

Powyższy podział pozwala łatwo sklasyfikować poszczególne usługi do jednej z tych dwóch grup. Umożliwia zatem, w dalszej kolejności, określić operatorom, co jest głównym składnikiem ich przychodów.

1.2. Monopol Telekomunikacji Polskiej SA na rynku usług telekomunikacyjnych w latach 1998-2000

Początek rynku usług telekomunikacyjnych w Polsce datowany jest na 1928 rok, kiedy to powstało polskie przedsiębiorstwo państwowe Polska Poczta, Telegraf i Telefon (PPTiT), będące, zgodnie $z$ regulacjami prawnymi, monopolistą na tym rynku. W 1991 roku nastąpiła jego likwidacja i powstanie spółki akcyjnej Skarbu Państwa o nazwie Telekomunikacja Polska. Zgodnie z Ustawą o łączności (1990), wykonywać działalność w dziedzinie telekomunikacji na rynku lokalnym mogła ta spółka oraz inne podmioty, które otrzymały zezwolenie. Formalnie nastąpiło zatem zakończenie monopolu państwowego. Jednak, na rynku telefonii międzynarodowej, jedynym operatorem, dopuszczonym do świadczenia usług została TP SA. Określone zostały również zakazy „na używanie urządzeń, linii i sieci telekomunikacyjnych bezpośrednio połączonych drogą kablową, radiową lub w układzie międzynarodowych systemów satelitarnych $z$ liniami, urządzeniami lub sieciami znajdującymi się poza granicami Rzeczypospolitej Polskiej - podmiotowi zagranicznemu lub spółce $z$ udziałem podmiotów zagranicznych" oraz „na używanie międzymiastowych linii i sieci telekomunikacyjnych oraz na świadczenie 
międzymiastowych usług telekomunikacyjnych - podmiotowi zagranicznemu lub spółce $z$ udziałem podmiotów zagranicznych, jeżeli udział podmiotów zagranicznych w kapitale zakładowym lub akcyjnym przekracza 49,0\%" (Ustawa o łączności, 1990). Ograniczenia te, $\mathrm{w}$ połączeniu z ogromnymi kosztami wejścia na rynek telekomunikacyjny wynikającymi z konieczności uzyskania licznych licencji i zezwoleń oraz utworzenia własnej sieci dostępowej, stanowily ogromną barierę $\mathrm{w}$ procesie liberalizacji branży telekomunikacyjnej. Nie bez znaczenia pozostawał również fakt, że realnym właścicielem TP SA było Ministerstwo Łączności, pełniące funkcję reprezentanta Skarbu Państwa, co powodowało powstawanie konfliktów interesów. Prowadziło ono politykę przyznawania zezwoleń operatorom na rynkach lokalnych, która często nie kierowała się interesem liberalizacji rynku, lecz raczej jego zwalczania. Operatorzy alternatywni byli również zobowiązani do ustalania planów inwestycyjnych $z$ TP SA, a związane $z$ nimi dokumenty, zawierające plany budowy sieci i harmonogram przyłączeń, dostarczano TP SA jako stronie umowy. Umyślne dofinansowywanie inwestycji w określonych miejscach, było prowadzone przez TP SA na podstawie wiedzy o planowanych inwestycjach innych operatorów (Raczyński, 2006, s. 298). Realnie więc $w$ branży telekomunikacyjnej był monopol, czyli sytuacja, gdzie występuje jedyny, faktyczny i potencjalny dostawca produktu lub usługi wytwarzanej w określonej gałęzi (Begg $\mathrm{i}$ in., 2007, s. 422).

W 1992 roku zaczął funkcjonować w Polsce rynek usług telefonii mobilnej, a jego pierwszym operatorem została Polska Telefonia Komórkowa Centertel Sp. z o.o. (dalej PTK Centertel), w którym 51,0\% udziałów była własnością TP SA. Operator ten mial również, od 1996 roku, przewagę w warunkach konkurencji monopolistycznej na rynku dostępu do Internetu. Posiadał zatem pozycję dominującą na każdym rynku usług telekomunikacyjnych w Polsce.

Istotnym motywem do rozpoczęcia procesów realnej liberalizacji rynku telekomunikacyjnego była chęć przystąpienia Polski do
Unii Europejskiej (UE). W tym celu należało dostosować polskie prawo do standardów europejskich, a zgodnie z Dyrektywą 96/19/ WE (1996), państwom członkowskim UE powierzono zadanie pełnej liberalizacji branży usług telefonicznych. Najważniejszym aspektem liberalizacji było udostępnienie publicznych sieci telekomunikacyjnych operatorom alternatywnym tak, aby umożliwić im dostarczanie usług $\mathrm{w}$ ramach powszechnej sieci telefonicznej (Budziewicz-Guźlecka, 2011, s. 108). Wśród zasadniczych celów liberalizacji branży telekomunikacyjnej w Polsce wymienianie były głównie (Rzepka, 1999, s. 14):

- rozwój infrastruktury,

- ochrona konsumenta,

- rozwój konkurencji,

- prywatyzacja TPSA,

- terminowe przystąpienie Polski do UE.

Ostatni, przytoczony cel oznaczal, że wszelkie regulacje musiały być zgodne $z$ wytycznymi unijnymi. Ministerstwo Łączności, do 2000 roku, nie podejmowało działań $\mathrm{w}$ zakresie kontroli cen $\mathrm{w}$ branży telekomunikacyjnej. Pozwalało to TP SA na dowolne ich kształtowanie oraz korzystanie $z$ instrumentów cenowych do likwidowania konkurencji ze strony operatorów alternatywnych (Raczyński, 2006, s. 299). Dyrektywa 97/33/ WE (1997), nakładała obowiązki: powołania urzędu regulacji telekomunikacyjnej, ustanowienia rynkowych cen oraz świadczenia usług powszechnych na odpowiednim poziomie. W Polsce, mimo istnienia konieczności opracowania i jak najszybszego wdrożenia w życie nowych rozwiązań regulacyjnych dotyczących branży telekomunikacyjnej, szybkość ich realizacji pozostawiała wiele do życzenia ( $\mathrm{Bu}$ dziewicz-Guźlecka, 2011, s. 108).

Jednym z głównych zaleceń UE, było również rozpoczęcie procesu prywatyzacji podstawowych sektorów gospodarki narodowej, w tym m.in. telekomunikacji. W 1997 roku Ministerstwo Skarbu Państwa przygotowało program prywatyzacji TP SA, który przewidywał jej trzy etapy. Pierwszy etap nastąpił w 1998 roku. Polegał on na wprowadzeniu TP SA na GPW w Warszawie oraz na GDR (Global Depositary Receipts) w Londynie, jak rów- 
nież na sprzedaży w ofercie publicznej 15,0\% akcji spółki. W 1999 roku zniesiono prawo o konieczności posiadania co najmniej 51,0\% akcji TP SA przez Skarb Państwa. W 2000 roku zaś dokonano drugiego etapu prywatyzacji, sprzedając 35,0\% akcji konsorcjum France Telecom i Kulczyk Holding, które tym samym stało się strategicznym inwestorem TP SA.

\subsection{Liberalizacja rynku usług telekomunikacyjnych w Polsce w latach 2001-2010}

1 stycznia 2001 roku weszła w życie ustawa Prawo telekomunikacyjne (2000), uchwalona 21 lipca 2000 roku. Była ona znaczącym krokiem $\mathrm{w}$ procesie liberalizacji branży telekomunikacyjnej w Polsce.

Podejmowano działania, aby polskie prawo telekomunikacyjne było coraz bardziej zgodne $z$ regulacjami unijnymi. Zlikwidowano koncesje, a konieczność uzyskiwania zezwoleń ograniczono tylko na eksploatacje publicznej sieci telefonicznej oraz sieci publicznej, przeznaczonej do rozpowszechniania i rozprowadzania programów radiofonicznych i telewizyjnych (Prawo telekomunikacyjne, 2000). W przypadku innej działalności telekomunikacyjnej, konieczne było wyłącznie zgłoszenie jej do Prezesa Urzędu Regulacji Telekomunikacji (URT), czyli nowego organu regulacyjnego, ustanowionego tą ustawą. Został on wyposażony w szerokie uprawnienia nadzorcze, kontrolne i władcze w stosunku do uczestników branży telekomunikacyjnej (Ura, 2001, s. 130). Nie otrzymał jednak możliwości stanowienia prawa. Bardzo istotną zmianą mającą ogromy wpływ na osłabienie pozycji TP SA jako monopolisty $w$ polskiej branży telekomunikacyjnej, było nakazanie podmiotom o znaczącej pozycji rynkowej umożliwienia korzystania ze swoich łączy innym operatorom. Ponadto, cena dzierżawy była zależna wyłącznie od faktycznego kosztu usługi dzierżawy, a dla ujednolicenia i przejrzystości umów nałożono obowiązek, aby podmioty przygotowały ramowe oferty określające warunki realizacji umowy dzierżawy (Kaczmarczyk, 2015, s. 80). Takie rozwiązanie było kluczowym punktem $\mathrm{w}$ procesie liberalizacji branży telekomunikacyjnej w Polsce. Wszelkie, kolejne zmiany już tylko go pogłębiały.

W 2001 roku zrealizowano trzeci etap w procesie prywatyzacji TP SA. Zostało pozyskane 12,5\% kolejnych akcji spółki przez Konsorcjum France Telecom i Kulczyk Holding. Francuski operator France Telecom w tym konsorcjum był podmiotem o większych prawach i posiadał perspektywę nabycia kolejnych udziałów.

1 stycznia 2002 roku nastąpiło pełne uwolnienie segmentu połączeń międzystrefowych, a w 2003 roku połączeń międzynarodowych. $\mathrm{Na}$ rynku telefonii stacjonarnej pojawiły się takie przedsiębiorstwa, jak: Netia SA, Telefonia Dialog Sp. z o.o., czy Tele2 Polska Sp. z o.o. Nadal jednak zdecydowaną, ponad 85,0\% przewage udziału $\mathrm{w}$ przychodach sektora, miała TP SA. Ceny usług połączeń stacjonarnych, przy braku znaczącej konkurencji na rynku, wciąż utrzymywały się na wysokim poziome. W 2002 roku URT został zastąpiony przez Urząd Regulacji Telekomunikacji i Poczty (URTiP). 1 października 2003 roku weszła w życie nowelizacja ustawy Prawo telekomunikacyjne (2004), wprowadzająca zmiany obejmujące zwiększenie zakresu możliwości abonentów odnoszących się do przenoszenia numerów (także przy zmianie operatora) oraz wyboru operatora i wdrożenia nowych regulacji dotyczących ofert ramowych, m.in. dzierżawy łączy (Budziewicz-Guźlecka, 2011, s. 110). Dla klientów oznaczało to brak konieczności zmiany numeru przy dokonaniu zmiany operatora. Był to kolejny krok w celu osłabienia pozycji TP SA na korzyść operatorów alternatywnych.

W związku z wstąpieniem Polski do UE 1 maja 2004 roku, konieczne było stworzenie nowej ustawy, która spełniałaby wymogi unijne. Zostały one określone $w$ tzw. nowym pakcie dyrektyw z 2002 roku, które wszystkie państwa członkowskie UE były zobowiązane wprowadzić do lipca 2003 roku. W Polsce wprowadzono je z opóźnieniem, uchwalając 16 lipca 2004 roku nowe Prawo telekomunikacyjne (2004), które weszło w życie 3 września 2004 roku. 
Głównym celem z ustawy z 2004 roku było zapewnienie użytkownikom maksymalnych korzyści ze świadczonych usług. W związku $z$ tym, została wprowadzona procedura konsultacji. Zgodnie $z$ art. 15 ustawy Prawo telekomunikacyjne (2004), uczestnicy rynku mogli przedstawić na piśmie swój punktu widzenia przed zapadnięciem decyzji w sprawach następujących:

- analizy rynku i wyznaczenia przedsiębiorcy telekomunikacyjnego o znaczącej pozycji rynkowej lub uchylenia decyzji w tej sprawie;

- nałożenia, zniesienia, utrzymania lub zmiany obowiązków regulacyjnych $\mathrm{w}$ stosunku do przedsiębiorcy telekomunikacyjnego o znaczącej pozycji lub nieposiadającego takiej pozycji;

- decyzji dotyczących dostępu telekomunikacyjnego.

Polska, jako państwo członkowskie UE, była zobowiązana do wprowadzenia także procedury konsolidacji, która miała zastosowanie wyłącznie wtedy, gdy postanowienia rynkowe oddziaływały na stosunki handlowe między państwami. Postępowanie to, według polskiego prawa, rozpoczynało się wraz $z$ procedurami konsultacyjnymi i dawało możliwość wydania opinii Komisji Europejskiej i urzędom regulacyjnym innych państw członkowskich UE na temat decyzji w sprawach zawartych $\mathrm{w}$ art. 15 . Umożliwiało to realne oddziaływanie organów europejskich na proces liberalizacji branży telekomunikacyjnej w Polsce. Ustawa również obejmowała zapisy, które przewidywały rezygnację ze sztywnej regulacji rynku telekomunikacyjnego i zastosowanie regulacji odnoszącej się do rzeczywistych warunków i potrzeb rynkowych (Kaczmarczyk, 2015, s. 80). Branża telekomunikacyjna została zatem skierowana przede wszystkim na polepszenie sytuacji konsumenta.

W 2004 roku skorzystano z jednej z klauzul zawartych w umowie między France Telecom a Kulczyk Holding i uzgodniono porozumienie o przeniesieniu $13,57 \%$ akcji TP SA, będących w posiadaniu Kulczyk Holding, na rzecz France Telecom. W 2005 roku na pol- skim rynku telekomunikacyjnym pojawiła się marka Orange, pod którą zaczęła działać PTK Centertel. W 2006 roku natomiast, URTiP został zastąpiony przez UKE, który otrzymał dodatkowo więcej uprawnień.

Prawo telekomunikacyjne (2009), nowelizowano jeszcze w 2009 roku i wprowadzono pewne poprawki mające na celu jeszcze bardziej pogłębioną liberalizację branży telekomunikacyjnej. Nowelizacja m.in. usunęła opłatę za przeniesienie numeru przy dokonaniu zmiany operatora publicznej sieci telefonicznej (Budziewicz-Guźlecka, 2011, s. 112).

W sierpniu 2010 roku Ministerstwo Skarbu Państwa sprzedało ostatnie 4,15\% akcji TP SA, kończąc ostatecznie proces prywatyzacji spółki. Proces liberalizacji branży telekomunikacyjnej (w tym szczególnie rynku telefonii stacjonarnej) cały czas trwał, jednak udało się zwiększyć udział $\mathrm{w}$ branży operatorów alternatywnych kosztem TP SA, która traciła pozycję monopolisty (UKE, 2011a, s. 61). Dla użytkowników zaś najważniejsze było to, że ceny usług telekomunikacyjnych z roku na rok malały.

\section{Przegląd literatury}

W literaturze przedmiotu istnieje luka poznawcza dotycząca opisu zależności między zakończonym procesem prywatyzacji TP SA a pozycją konkurencyjną Grupy Orange.

M. Raczyński (2006), krytykuje przebieg procesu prywatyzacji TP SA, wysuwając tezę, że władze ustawodawcze i wykonawcze świadomie tworzyły słabe instytucje regulujące sektor telekomunikacyjny, tak aby nie były one zdolne do przeciwstawienia się grupom nacisku.

A. Budziewicz-Guźlecka (2011), wskazuje na aspekt dostosowywania polskiego prawa telekomunikacyjnego do wymogów unijnych, który był kluczowy dla całego przebiegu procesu prywatyzacji TP SA.

P. Kaczmarczyk (2015), analizując rozwój rynku telefonii mobilnej wskazuje, że był to rynek branży telekomunikacyjnej, na którym najszybciej pojawiła się konkurencja dla operatora dominującego. 
W raportach UKE (2012a-2017a), opisana jest sytuacja na poszczególnych rynkach branży telekomunikacyjnej $\mathrm{w}$ Polsce. Ukazane jest, że rynki usług telekomunikacyjnych $\mathrm{w}$ Polsce $\mathrm{w}$ całym analizowanym okresie podlegały rozwojowi, a walka konkurencyjna na nich $z$ roku na rok się zaostrzała.

\section{Metody}

$\mathrm{W}$ artykule zostały wykorzystane różne źródła i metody badawcze. W części teoretycznej użyte zostały opracowania zwarte oraz artykuły dotyczące tematyki rynku usług telekomunikacyjnych. Materiał empiryczny stanowią raporty UKE. Wśród użytych metod badawczych wymienić można analizę opisową i porównawczą.

\section{Wyniki badania}

\subsection{Specyfika branży telekomunikacyjnej w Polsce latach 2011-2016}

Cechą charakterystyczną branży telekomunikacyjnej w Polsce był fakt, że podlegała ona ciągłym przekształceniom. Z każdym rokiem coraz bardziej zaostrzała się walka konkurencyjna między operatorami, a w związku z tym taniały oferowane usługi, jak również następował ich szybki rozwój.

$\mathrm{Na}$ wykresie 1. przedstawiona została wartość branży telekomunikacyjnej $\mathrm{w}$ Polsce w latach 2011-2016. W latach 2011-2014 charakteryzowała się ona tendencją spadkową. Niewielki wzrost można było zauważyć dopiero w 2015 roku. Przyczyn takiego stanu rzeczy było wiele. Po pierwsze, spowodowane było to natężeniem walki konkurencyjnej $\mathrm{w}$ branży telekomunikacyjnej, która prowadziła do ciągłego obniżania cen usług. Ważnym aspektem był również fakt, że w każdym $z$ omawianych lat, spora liczba abonentów rezygnowała $z$ korzystania $z$ telefonów stacjonarnych. Pojawily się ponadto oferty konwergentne, które łączyły usługi mobilne i stacjonarne $\mathrm{w}$ jeden pakiet i umożliwiały użytkowanie ich po cenie niższej, niż w przypadku indywidualnego zakupu. W związku z tym, w 2011 roku wartość branży telekomunikacyjnej była najwyższa $\mathrm{w}$ analizowanych latach (43,0 mld PLN). W 2014 roku spadła ona do najniższego poziomu $\mathrm{w}$ analizowanych latach wynoszącego 39,2 mld PLN. W 2015 roku natomiast nieznacznie wzrosła do 39,5 mld PLN i utrzymała się na tym poziomie w 2016 roku. W latach 2011-2016 nastąpił zatem spadek wartości branży telekomunikacyjnej o 3,5 mld PLN.

UKE (2012a-2017a), w raportach o stanie branży telekomunikacyjnej w Polsce, dzieli usługi telekomunikacyjne na rynki: telefonii stacjonarnej, telefonii ruchomej, dostępu do Internetu, a od 2014 roku również usług wiązanych. Wszystkie te rynki posiadają swoją odrębną specyfikę, w zawiązku z tym każdy $z$ nich został omówiony oddzielnie.

\subsubsection{Specyfika rynku telefonii stacjonarnej w Polsce w latach 2011-2016}

Główną cechą najstarszego rynku powszechnych usług telekomunikacyjnych w Polsce, czyli telefonii stacjonarnej, był stały spadek jego popularności (wykres 2.). Na podstawie danych przedstawionych na wykresie 2., można wyciągnąć kilka wniosków. W analizowanych latach, liczba abonentów tego rodzaju komunikacji znacznie malała, rok rocznie średnio o 0,6 mln. W 2011 roku wynosiła ona 7,9 mln, a w 2016 roku już tylko 5,2 mln. Sytuacja ta wynikała przede wszystkim $z$ faktu substytucji telefonii stacjonarnej telefonią mobilną. Zaznaczyć należy, że taki sposób kontaktowania się był szczególnie popularny wśród starszych osób, które były przyzwyczajone do korzystania $z$ telefonii stacjonarnej (UKE, 2015b), a których $z$ roku na rok było mniej.

$\mathrm{Na}$ wykresie 3. przedstawione zostały średnie, miesięczne przychody, uzyskiwane przez operatorów z jednego abonenta telefonii stacjonarnej $\mathrm{w}$ Polsce. Wartość ta $\mathrm{w}$ analizowanych latach malała, z wyjątkiem 2013 roku. W 2011 roku użytkownik tego rodzaju usługi płacił przeciętnie 55,4 PLN miesięcznie, 
w 2016 roku natomiast już tylko 41,2 PLN. $\mathrm{Na}$ takie kształtowanie się danych największy wpływ miało nasilenie się walki konkurencyjnej wewnątrz segmentu oraz spadek popytu zgłaszanego przez konsumentów na usługi telefonii stacjonarnej, co skutkowało obniżaniem cen usług.

$\mathrm{Na}$ wykresie 4. została przedstawiona wartość rynku telefonii stacjonarnej w Polsce w latach 2011-2016. Naturalną konsekwencją spadku liczby abonentów oraz zmniejszenia się wartości miesięcznych przychodów per capita, był spadek całkowitej wartości rynku telefonii stacjonarnej. W 2011 roku wynosiła ona 5,2 mld PLN, w kolejnych, analizowanych latach charakteryzowała się tendencją spadkową. W 2016 roku spadła do najniższego poziomu w omawianych latach (2,6 mld PLN). Był to największy spadek wartości, biorąc pod uwagę wszystkie rynki branży telekomunikacyjnej.

Można zauważyć, że rynek telefonii stacjonarnej był rynkiem w schyłkowej fazie rozwoju. Negatywna tendencja występująca na tym rynku, w kolejnych latach jeszcze bardziej powinna się pogłębiać. Przyczyny jej powstania takie, jak: zastępowanie telefonów stacjonarnych telefonami komórkowymi oraz zmniejszanie się liczby osób starszych, które dotychczas korzystały z usług telefonii stacjonarnej, będą nieuchronnie postępować.

\subsubsection{Specyfika rynku telefonii ruchomej w Polsce w latach 2011-2016}

Specyfiką rynku telefonii mobilnej była jego duża popularność (wykres 5.) oraz malejące ceny usług. W latach 2011-2014 rosła nominalna liczba użytkowników telefonii ruchomej (mierzona ilością kart SIM (Subscriber Identity Module)). W latach 2015 i 2016 nastąpił jej niewielki spadek do poziomu odpowiednio 56,6 i $55,5 \mathrm{mln}$ użytkowników. Wynikał on przede wszystkim $z$ działań pewnych operatorów telekomunikacyjnych, których celem była eliminacja nieaktywnych kart SIM (UKE, 2015b).

$\mathrm{Na}$ wykresie 6. został przedstawiony wskaźnik nasycenia rynku telefonii ruchomej w Polsce w latach 2011-2016. Jest to „pomiar wielkości sprzedaży produktu w stosunku do liczby potencjalnych klientów, wyrażony w procentach" (Business Dictionary, 2017). W przypadku rynku telefonii mobilnej, oblicza się go dzieląc liczbę kart SIM w posiadaniu użytkowników przez liczbę wszystkich mieszkańców Polski, którzy stanowią grupę docelową. Na podstawie danych przedstawionych na wykresie 6. zauważyć można, że wskaźnik ten wskazuje wręcz na przesycenie rynku telefonii ruchomej. Liczba kart SIM w użytku była większa od liczby mieszkańców Polski. Baza klientów telefonii mobilnej w Polsce została, zatem już w zdecydowanym stopniu zagospodarowana i wzrost nominalnej liczby użytkowników w najbliższych latach będzie zależał przede wszystkim od klientów, którzy decydować się będą na posiadanie więcej niż jednej karty SIM.

Średni, miesięczny przychód $z$ abonenta telefonii mobilnej $\mathrm{w}$ Polsce $\mathrm{w}$ latach 2011-2015 został przedstawiony na wykresie 7. Wraz ze wzrostem nominalnej liczby abonentów telefonii ruchomej, spadał średni, miesięczny przychód, uzyskiwany przez operatorów $z$ jednego użytkownika usług. W 2011 roku, przedsiębiorcy telekomunikacyjni zarabiali średnio 31,6 PLN z jednego abonenta, w 2015 roku wartość ta wynosiła już tylko 25,3 PLN. Główny wpływ na taką sytuację miała nasilająca się walka konkurencyjna na tym rynku, której skutkiem było obniżanie cen usług.

$\mathrm{Na}$ wykres 8. została zaprezentowana wartość rynku telefonii ruchomej w Polsce w latach 2011-2016. Wzrost liczby abonentów nie powodował wzrostu wartości rynku usług telefonii ruchomej, na co wpływ miał spadek średniego przychodu per capita. W 2011 roku wynosiła ona 19,0 mld PLN, jednak z każdym rokiem malała, a w 2016 roku osiągnęła najniższy poziom (16,7 mld PLN).

Według raportów UKE (2012a-2017a), rynek telefonii ruchomej $\mathrm{w}$ analizowanych latach był najbardziej dochodowym ze wszystkich rynków telekomunikacyjnych w Polsce. Jego udziały w całkowitej wartości rynku rok rocznie przekraczały $40,0 \%$. $Z$ tego względu był on najbardziej znaczący dla wszystkich 
operatorów. Jest to jednak już rynek dojrzały, który nie ma znaczących perspektyw dalszego rozwoju.

\subsubsection{Specyfika rynku dostępu do Internetu w Polsce w latach 2011-2016}

Rynek usług dostępu do Internetu charakteryzował się głównie ciągłym wzrostem wartości oraz zwiększającą się liczbą użytkowników (wykres 9.). Wskaźnik nasycenia Internetem szerokopasmowym oblicza się w stosunku do wszystkich mieszkańców, lecz co ważniejsze, również $\mathrm{w}$ odniesieniu do wszystkich gospodarstw domowych danego państwa. Zakłada się, że zwykle Internet użytkowany jest przez wszystkich domowników danego obiektu mieszkalnego. Poziom obu wskaźników w latach 2011-2016 rósł. Rok 2015 był pierwszym rokiem, w którym występowało ponad 100,0\% pokrycie gospodarstw domowych usługą dostępu do Internetu (UKE, 2015b).

Średni, miesięczny przychód $z$ abonenta rynku dostępu do Internetu w Polsce w latach 2011-2016 zostal przedstawiony na wykresie 10. Jego wartość $w$ analizowanych latach rosła do 2013 roku, gdy osiągnęła najwyższą wartość (ponad 35,0 PLN). Wzrost ten można wytłumaczyć pojawieniem się droższych ofert dotyczących najbardziej zaawansowanych technologii. W kolejnych latach wartość przychodów była coraz niższa, a w 2016 roku spadła do poziomu 28,2 PLN. Podobnie, jak w przypadku pozostałych rynków telekomunikacyjnych, można to wytłumaczyć coraz silniejszą walką konkurencyjną, która powodowała obniżkę cen usług.

$\mathrm{Na}$ wykresie 11. została przedstawiona wartość rynku dostępu do Internetu w Polsce w analizowanych latach. W latach 2011-2013 rosła liczba abonentów rynku dostępu do Internetu w Polsce, jak również średni przychód $z$ nich uzyskiwany. Prostą konsekwencją tego był wzrost całkowitej wartości rynku $\mathrm{w}$ tych latach. W 2014 roku spadek przeciętnego poziomu przychodów uzyskiwanych $z$ jednego użytkownika, zrekompensował $z$ nadwyżką wzrost liczby abonentów tego rodzaju usługi.
W 2016 roku wartość rynku dostępu do Internetu spadła do poziomu osiaggniętego $\mathrm{w}$ roku poprzednim (5,1 mld PLN).

Rynek usług dostępu do Internetu jest już znacznie nasycony. W analizowanych latach wartość rynku rosła i dołączyło do niego wielu nowych abonentów. Perspektywy rozwoju tego rynku jednak nadal występują, przede wszystkim $\mathrm{w}$ obszarze Internetu mobilnego, który $\mathrm{w}$ ostatnim okresie zyskiwal na popularności.

\subsubsection{Specyfika rynku usług wiązanych w Polsce w latach 2011-2016}

Pakietyzacja usług jest jedną $z$ najbardziej zauważalnych tendencji $\mathrm{w}$ polskiej branży telekomunikacyjnej. Na wykresie 12. została zaprezentowana liczba abonentów usług wiązanych w Polsce w latach 2011-2016. Od 2013 roku stale rosła liczba abonentów usług wiązanych w Polsce. Największy wzrost można było zaobserwować między 2014 a 2016 rokiem, kiedy to pojawiło się ponad 4,0 $\mathrm{mln}$ nowych użytkowników, którzy zaczęli korzystać $z$ ofert konwergentnych. Nie powinno to dziwić, biorąc pod uwagę fakt, że usługi w pakiecie sprzedawane były często ze zniżką, co oczywiście było korzystne dla klientów. Operatorzy również chętnie podpisywali umowy obejmujące tego rodzaju oferty, w ten sposób mogli bardziej związać ze sobą abonentów.

W tabeli 1. zaprezentowany został udział poszczególnych pakietów usług telekomunikacyjnych w Polsce w latach 2011-2016. Do 2014 roku najbardziej popularny pakiet usług obejmowal Internet stacjonarny i telewizję. W 2015 roku już jednak zdecydowanie największa liczba użytkowników (41,2\%), korzystała $z$ oferty konwergentnej składającej się $z$ telefonii ruchomej i Internetu mobilnego.

Rynek usług wiązanych w Polsce, w warunkach rozwijającego się społeczeństwa informacyjnego, $z$ pewnością nie jest jeszcze całkowicie nasycony. Możliwe jest dalsze jego zagospodarowanie, gdyz pakietyzacja usług jest korzystna pod względem ekonomicznym, zarówno dla konsumenta, jak i producenta. 
4.2. Pozycja Grupy Kapitałowej Orange Polska w branży telekomunikacyjnej w latach 2011-2016

Pozycja Grupy Orange w branży telekomunikacyjnej $\mathrm{w}$ Polsce, omówiona zostanie na podstawie udziałów w poszczególnych jej rynkach. 31 grudnia 2013 roku nastąpiło połączenie TP SA, PTK Centertel oraz Orange Polska sp. $z$ o.o. $w$ jeden podmiot Orange Polska SA, w związku z czym Grupa Kapitałowa Telekomunikacja Polska zmieniła nazwę na Orange Polska. Ze względu na przyjęty w niniejszej pracy zakres czasowy, fuzja ta zostanie uwzględniona podczas opisywania zmian zachodzących $\mathrm{w}$ poszczególnych rynkach branży.

\subsubsection{Pozycja Grupy Kapitałowej Orange Polska na rynku telefonii stacjonarnej w latach 2011-2016}

Grupa Orange, jako dawny monopolista na rynku usług telefonii stacjonarnej w Polsce, we wszystkich, analizowanych latach utrzymywała na nim pozycje dominującą (tabela 2.). Udział Orange Polska, pod względem liczby abonentów telefonii stacjonarnej, zmniejszył się w 2012 roku o 6,9 p.p. w odniesieniu do roku poprzedniego. W kolejnych, czterech latach podlegał on niewielkim wahaniom $w$ granicach $+/-2,0$ p.p. Pokazuje to, że abonenci związani $z$ TP SA w sytuacji, gdy była ona jeszcze przedsiębiorstwem monopolistycznym, rzadko kiedy decydowali się na dokonanie zmiany operatora $w$ warunkach rynku zliberalizowanego.

W tabeli 3. został przedstawiony udział operatorów pod względem przychodów rynku telefonii stacjonarnej w Polsce w latach 20112015. Orange Polska utrzymywała, we wszystkich, analizowanych latach, ponad 50,0\% udział pod względem przychodów na rynku telefonii stacjonarnej. W latach 2013-2015 był on jednak nieznacznie mniejszy w porównaniu $z$ udziałem w liczbie abonentów (tabela 2.). Największy wpływ na to miał duży w tym okresie, wahający się w okolicach $20,0 \%$, udział Netii, której usługi były całościowo droższe, niż usługi operatora dominującego na rynku.
Pozycja Orange Polska na rynku telefonii stacjonarnej, mimo postępującego procesu jego liberalizacji, wciąż była zdecydowanie najbardziej znacząca. Jest to jednak rynek w schyłkowej fazie rozwoju, z którego przychody, w perspektywie najbliższych kilku lat, mogą stać się marginalne $\mathrm{w}$ odniesieniu do całości przychodów Grupy Orange.

\subsubsection{Pozycja Grupy Kapitałowej Orange Polska na rynku telefonii ruchomej w latach 2011-2016}

$\mathrm{Na}$ rynku przynoszącym największe przychody, spośród wszystkich rynków branży telekomunikacyjnej $\mathrm{w}$ Polsce, czyli telefonii ruchomej, Orange Polska w analizowanych latach było jednym $z$ najbardziej dominujących operatów (tabela 4.). Rynek telefonii mobilnej w latach 2011-2016 został zdominowany przez czterech operatorów, mimo że funkcjonowało na nim dwadzieścia siedem przedsiębiorstw telekomunikacyjnych. W każdym $z$ omawianych lat, ich łączny udział wynosił ponad 96,0\% udziałów w rynku w odniesieniu do liczby abonentów. Najlepszym pod tym względem dla Orange Polska był 2011 rok (29,2\% udział). W trzech, kolejnych latach największa ilość klientów korzystała $z$ usług T-Mobile Polska. W 2015 i 2016 roku jednak straciło ono znaczne udziały w rynku, przede wszystkim na rzecz P4 (operator sieci Play), jak również na rzecz Orange Polska, które ponownie stało się liderem rynku pod względem liczby abonentów.

Udział operatorów pod względem przychodów rynku telefonii ruchomej w Polsce $\mathrm{w}$ analizowanych latach został zaprezentowany w tabeli 5. Gorszy, niż w przypadku liczby abonentów (tabela 4.), był dla Orange Polska trend dotyczący udziału w wielkości przychodów na rynku (tabela 5.). Z każdym rokiem był on mniejszy, na rzecz P4, które w coraz większym stopniu partycypowało $\mathrm{w}$ wartości rynku. Przedsiębiorstwem dominującym pod tym względem, we wszystkich analizowanych latach, był Polkomtel (operator sieci Plus), przykładający bardzo dużą wagę do oferowania usług o najwyższej jakości technologicznej, co również miało odbicie w ich cenie. 
W tabeli 6. został przedstawiony bilans przenośności numerów na rynku telefonii ruchomej w Polsce w latach 2011-2016. W okresie tym ponad 7,0 mln Polaków przeniosło swój numer do innego operatora. Bilans przenośności numerów dla Orange Polska, jak również Polkomtel oraz T-Mobile Polska, w analizowanym okresie był ujemny. W przypadku operatora o pozycji znaczącej, ten negatywny trend w latach 2012-2015 miał charakter zniżkowy, w odróżnieniu od dwóch, pozostałych przedsiębiorstw (Polkomtel i T-Mobile Polska). Bardzo duży, rokroczny przyrost liczby abonentów dotyczył natomiast P4, które prowadziło bardzo efektywną kampanię marketingową. W najbliższej przyszłości operator ten może stać się liderem rynku telefonii ruchomej.

Na rynku usług telefonii ruchomej występowała bardzo duża rywalizacja między czterema operatorami posiadającymi największe udziały w rynku. Orange Polska miała na nim silną pozycję, która $z$ roku na rok nieznacznie słabła, przede wszystkim pod względem udziału w całkowitych przychodach rynku. Ze względu na największą wartość tego rynku, spośród wszystkich rynków branży telekomunikacyjnej, należy się spodziewać, że podmioty dotychczas już konkurujące z Grupą Orange, podejmą kolejne działania zmierzające do intensyfikacji swojego rozwoju, na co musi być ona gotowa, jeżeli nadal chce utrzymać swoją dominującą pozycję.

\subsubsection{Pozycja Grupy Kapitałowej Orange Polska na rynku dostępu do Internetu w latach 2011-2016}

$\mathrm{Na}$ rynku dostępu do Internetu, który rozwijał się najbardziej dynamicznie w ostatnim okresie spośród wszystkich rynków branży telekomunikacyjnej, Orange Polska posiadało $\mathrm{w}$ analizowanych latach pozycję niekwestionowanego lidera (tabela 7.). Orange Polska, $\mathrm{w}$ omawianych latach, posiadało przynajmniej $30,0 \%$ udział w rynku pod względem liczby użytkowników Internetu w Polsce, $z$ wyjątkiem roku 2014 (29,1\%). Na tym rynku telekomunikacyjnym nie istniał żaden konkurent, który mógłby zagrozić pozycji operatora dominującego. Wynikało to głównie z faktu, $\dot{z}$ e Grupa Orange dostarczała swoje usługi internetowe zarówno w sieci stacjonarnej, jak i mobilnej, w odróżnieniu od innych przedsiębiorstw telekomunikacyjnych.

Udział operatorów w ogólnej liczbie użytkowników Internetu stacjonarnego w Polsce w latach 2011-2015 został zaprezentowany w tabeli 8. W segmencie usług stacjonarnego dostępu do Internetu, Orange Polska miało $\mathrm{w}$ analizowanych latach jeszcze większą przewagę nad konkurencją pod względem liczby użytkowników, niż w przypadku całego systemu sieciowego. W szczytowym 2012 roku, udział na tym rynku wyniósł 42,9\%. Od 2013 roku poziom ten systematycznie obniżał się do 30,0\% w 2015 roku. Warto zwrócić uwagę, że przedsiębiorstwa telekomunikacyjne takie, jak Polkomtel, P4, czy T-Mobile, które miały swój znaczny udział w całym rynku dostępu do Internetu, nie oferowały usług stacjonarnego dostępu do Internetu, lecz wyłącznie koncentrowały się na usługach mobilnych, które w ostatnim okresie coraz bardziej zyskiwały na znaczeniu.

Pozycja Orange Polska na rynku dostępu do Internetu $\mathrm{w}$ analizowanych latach, mimo pewnego, zauważalnego trendu spadkowego, była wciąż zdecydowanie dominująca. Konkurencja na tym rynku była znacznie rozdrobniona i żaden $z$ operatorów alternatywnych nie posiadał $\mathrm{w}$ analizowanym okresie nawet $11,0 \%$ udziału na tym rynku telekomunikacyjnego. Ze względu na fakt, że jest to rynek cały czas rozwijający się, sytuacja ta jest szansą dla Orange Polska na zwiększenie przychodów $z$ tego rynku w kolejnych latach.

\subsubsection{Pozycja Grupy Kapitałowej Orange Polska na rynku usług wiązanych w latach 2011-2016}

Na najmłodszym z głównych rynków telekomunikacyjnych, Orange Polska był jednym $z$ głównych jego operatorów $w$ analizowanych latach (wykres 13.). W latach 2011-2013 Orange Polska posiadało najwięcej abonentów najpopularniejszego wówczas pakietu telewi$z j a+$ Internet stacjonarny. Największy udział pod tym względem w całości rynku, odnoto- 
wano w 2011 roku (ponad 45,0\%). W 2013 roku udział zmniejszył się do poziomu $33,1 \%$, jednak nadal był on najwyższy na całym rynku.

$\mathrm{Na}$ wykresie 14. przedstawiony został udział operatorów w ogólnej liczbie użytkowników usług wiązanych w Polsce w latach 2014-2016. W 2014 roku Orange Polska było liderem na rynku usług wiązanych. W 2015 i 2016 roku większą liczbę użytkowników posiadało już $\mathrm{P} 4$, w wyniku marketingowych działań podjętych przez tego operatora telekomunikacyjnego $\mathrm{w}$ celu zdobycia nowych klientów.

Rynek usług wiązanych rozwiał się $w$ analizowanym okresie $\mathrm{w}$ dynamicznym tempie, co w najbliższych latach powinno dalej postępować. Orange Polska posiadało na tym rynku swój znaczny udział, a biorąc pod uwagę dotychczasowy rozwój tego rynku telekomunikacyjnego, powinno starać się o zdobycie na nim coraz większej ilości klientów.

\section{Zakończenie}

Branża telekomunikacyjna w Polsce w okresie trwającej transformacji ustrojowej ulegała znacznym przekształceniom. Początkowy monopol TP SA, był utrzymywany dzięki regulacjom utrudniającym wejście na rynek operatom alternatywnym. Perspektywa akcesji Polski do UE spowodowała rozpoczęcie intensywnego procesu liberalizacji branży telekomunikacyjnej, jak również procesu prywatyzacji TP SA. W skutek tego pojawiła się konkurencja na rynkach usług telekomunikacyjnych. Rozpoczęcie działalności wielu operatorów alternatywnych, znacznie osłabiło monopolistyczną pozycję TP SA, która w 2010 roku została ostatecznie sprywatyzowana.

Celem niniejszego artykułu było wykazanie wpływu prywatyzacji TP SA, któremu towarzyszyła liberalizacja branży telekomunikacyjnej, na pozycje konkurencyjną Grupy Orange. Analiza tego oddziaływania przeprowadzona została w podziale na poszczególne rynki telekomunikacyjne $\mathrm{w}$ Polsce. $\mathrm{Na}$ jej podstawie, uprawnione jest wyciągnięcie kilku wniosków.
Po pierwsze, na rynku telefonii stacjonarnej, który znajdował się w schyłkowej fazie rozwoju, były monopolista, mimo rosnącej konkurencji ze strony operatorów alternatywnych, nadal utrzymywał pozycję dominującą. Znacznie tego rynku jednak $z$ roku na rok było coraz mniejsze, ze względu na rezygnację znaczniej części użytkowników z korzystania $z$ tego typu komunikacji.

Po drugie, zintensyfikowana walka konkurencyjna na rynku telefonii mobilnej, który był $\mathrm{w}$ analizowanych latach najbardziej dochodowym ze wszystkich rynków telekomunikacyjnych w Polsce, powodowała obniżanie cen usług, a w konsekwencji obniżanie wartości całego rynku telefonii ruchomej. Grupa Orange posiadała na nim w latach 2011-2016 największy udział, który jednak z rok na rok nieznacznie malał na korzyść operatorów alternatywnych.

Po trzecie, najbardziej dynamicznie rozwijającym się rynkiem telekomunikacyjnym w Polsce w analizowanych latach był rynek dostępu do Internetu. Udział Orange Polska na nim, we wszystkich analizowanych latach, był dominujący, jednak podlegał trendowi spadkowemu. Konkurencja na tym rynku była mocno rozdrobniona, $w$ związku $z$ tym, żaden $z$ operatorów alternatywnych nie uzyskał takich udziałów w rynku, które zagroziłyby pozycji operatora dominującego.

Po czwarte, coraz większa popularność ofert konwergentnych, których zadaniem było przyciągnie nowych klientów atrakcyjnością cenową usług sprzedawanych w pakiecie, spowodowała rozwój rynku usług wiązanych w analizowanym okresie. Grupa Orange również na tym rynku posiadała znaczne udziały.

Prywatyzacja TP SA, z towarzysząca liberalizacją branży telekomunikacyjnej, spowodowała zatem zwiększenie konkurencji, co $z$ kolei wywołało obniżenie cen usług telekomunikacyjnych, a więc i obniżenie całkowitej wartości branży telekomunikacyjnej w Polsce. Grupa Orange w analizowanych latach systematycznie traciła swoje udziały na poszczególnych rynkach telekomunikacyjnych na rzecz operatorów alternatywnych. 


\section{Bibliografia}

Babis, H., i Czaplewski, R. (2011). Usługi telekomunikacyjne. W: H. Babis, i K. Flaga-Gieruszyńska (red.), Rynek ustug telekomunikacyjnych. Warszawa: Wolters Kluwer Business.

Begg, D., Fischer, S., i Dornbusch, R. (2007). Mikroekonomia. Warszawa: PWE.

Budziewicz-Guźlecka, A. (2011). Przekształcenia polskiego rynku usług telekomunikacyjnych. W: H. Babis, i K. Flaga-Gieruszyńska (red.), Rynek ustug telekomunikacyjnych. Warszawa: Wolters Kluwer Business.

Business Dictionary. (2017). Pobrane 24.03.2017 z http://www.businessdictionary.com.

Dyrektywa 96/19/WE z dnia 13 marca 1996 r. o konkurencji na rynkach telekomunikacyjnych (Dz.U. L 74 z 22.3.1996).

Dyrektywa 97/33/WE z dnia 30 czerwca 1997 r. w sprawie wzajemnych połączeń w telekomunikacji (Dz.U. L 199 z 26.7.1997).

Kaczmarczyk, P. (2015). Analiza rozwoju rynku telefonii mobilnej w Polsce w latach 2002-2013. Kwartalnik Kolegium Ekonomiczno-Spotecznego Studia i Prace, 1(21).

Raczyński, M. (2006). Reforma sektora telekomunikacyjnego. W: D. Kopycińska (red.), Regulacyjna rola państwa we wspótczesnej gospodarce. Szczecin: Printgroup.

Rzepka, P. (1999). Tworzenie rynku telekomunikacyjnego - deregulacja monopolisty szansą czy zagrożeniem dla rozwoju sektora? W: K. Olechowska (red.), Deregulacja monopoli naturalnych na przykładzie rynku telekomunikacyjnego. Warszawa: Centrum Analiz Społeczno-Ekonomicznych.
Telepolis. (2012-2017). Raport o przenośności numerów za lata 2011-2016. Pobrane 19.01.2018 $z$ http://telepolis.pl.

UKE. (2011a-2017a). Raport o stanie rynku telekomunikacyjnego $w$ Polsce za lata 2010-2016. Pobrane 22.03.2017 z https://www.uke.gov.pl.

UKE. (2015b). Rynek ustug telekomunikacyjnych w Polsce w 2015 roku. Badanie klientów indywidualnych w wieku 50+. Pobrane 23.03.2017 z https://www.uke.gov.pl.

Ura, E. (2001). Prawo telekomunikacyjne. Komentarz. Warszawa: Wydawnictwo Prawnicze.

Ustawa z dnia 16 lipca 2004 r. Prawo telekomunikacyjne (Dz.U. $2004 \mathrm{nr} 171$ poz. 1800).

Ustawa z dnia 21 lipca 2000 r. Prawo telekomunikacyjne (Dz.U. $2000 \mathrm{nr} 73$ poz. 852).

Ustawa z dnia 23 listopada 1990 r. o łączności (Dz.U. $1990 \mathrm{nr} 86$ poz. 504).

Ustawa z dnia 24 kwietnia 2009 r. o zmianie ustawy Prawo telekomunikacyjne oraz niektórych innych ustaw (Dz.U. 2009 nr 85 poz. 716).

Zygadlewicz, M. (2017). Prywatyzacja na rynku telekomunikacyjnym $w$ Polsce a sytuacja finansowa Grupy Kapitałowej Orange Polska. Nieopublikowana praca licencjacka, Uniwersytet Mikołaja Kopernika, Toruń.

Informacje uzupełniające

Wkład autorski: autor zaakceptował ostateczną wersję artykułu.

Źródła finansowania: artykuł został w całości sfinansowany ze środków własnych autora.

Uwagi: wyniki badania były zaprezentowane $w$ innej formie, tj. pracy licencjackiej Zygadlewicz (2017). 
Aneks

Tabela 1 .

Udział pakietów usług telekomunikacyjnych w liczbie abonentów ogółem w Polsce w latach 2011-2016 $(\mathrm{w} \%)$

\begin{tabular}{lrrrrrr}
\hline \multicolumn{1}{c}{ Pakiet } & 2011 & 2012 & 2013 & 2014 & 2015 & 2016 \\
\hline telefonia ruchoma i Internet mobilny & 10,0 & 12,8 & 16,0 & 15,2 & 41,2 & 53,7 \\
Internet stacjonarny i telewizja & 48,1 & 50,6 & 45,6 & 30,0 & 18,0 & 13,9 \\
telefonia stacjonarna, Internet stacjonarny i telewizja & 16,4 & 24,2 & 28,3 & 18,8 & 12,4 & 10,2 \\
telefonia stacjonarna i Internet stacjonarny & 15,1 & 4,3 & 3,6 & 10,9 & 4,6 & 2,9 \\
pozostałe & 10,4 & 8,1 & 6,5 & 25,0 & 23,8 & 19,3 \\
\hline
\end{tabular}

Źródło: Opracowanie własne na podstawie UKE (2012a-2017a).

Tabela 2 .

Udział operatorów w ogólnej liczbie abonentów telefonii stacjonarnej w Polsce w latach 2011-2016 (w \%)

\begin{tabular}{lrrrrrr}
\hline \multicolumn{1}{c}{ Operator } & 2011 & 2012 & 2013 & 2014 & 2015 & 2016 \\
\hline Orange Polska (wcześniej TP SA) & 62,6 & 55,7 & 56,9 & 56,1 & 55,1 & 54,7 \\
Netia & 10,7 & 11,2 & 10,8 & 8,0 & 9,6 & 9,1 \\
Telefonia Dialog & 5,5 & 5,3 & 4,7 & 2,2 & 3,5 & 3,2 \\
UPC & 3,8 & 6,3 & 7,7 & 8,7 & 10,4 & 12,1 \\
Vectra & 1,5 & 1,9 & 2,3 & 2,8 & 3,3 & 3,7 \\
T-Mobile (wcześniej PTC) & 3,4 & 3,6 & 3,5 & 3,4 & 3,2 & 3,1 \\
Multimedia Polska & 2,3 & 2,5 & 2,8 & 3,0 & 3,1 & 3,1 \\
pozostali & 12,5 & 16,0 & 14,1 & 18,8 & 13,2 & 11,0 \\
\hline
\end{tabular}

Źródło: Opracowanie własne na podstawie UKE (2012a-2017a).

Tabela 3.

Udział operatorów pod względem przychodów rynku telefonii stacjonarnej w Polsce w latach 2011-2015 $(\mathrm{w} \%)$

\begin{tabular}{lrrrrr}
\hline \multicolumn{1}{c}{ Operator } & 2011 & 2012 & 2013 & 2014 & 2015 \\
\hline Orange Polska (wcześniej TP SA) & 60,6 & 57,4 & 52,1 & 54,1 & 54,6 \\
Netia & 15,7 & 14,6 & 22,3 & 20,5 & 19,2 \\
Telefonia Dialog & 5,5 & 5,8 & 4,8 & 4,1 & 5,0 \\
UPC & 2,5 & 4,4 & 4,8 & 4,7 & 4,2 \\
Vectra & 0,6 & 0,8 & 0,9 & 1,1 & 3,0 \\
T-Mobile (wcześniej PTC) & 2,0 & 2,3 & 2,2 & 2,0 & 3,0 \\
NOVUM & 1,7 & 2,4 & 2,3 & 1,9 & 1,5 \\
pozostali & 11,4 & 12,3 & 10,6 & 11,6 & 9,5 \\
\hline
\end{tabular}

Uwagi:

Ze względu na brak danych pominięto 2016 rok.

Źródło: Opracowanie własne na podstawie UKE (2012a-2016a). 
Tabela 4.

Udział operatorów w ogólnej liczbie abonentów telefonii ruchomej w Polsce w latach 2011-2016 (w \%)

\begin{tabular}{lrrrrrr}
\hline \multicolumn{1}{c}{ Operator } & 2011 & 2012 & 2013 & 2014 & 2015 & 2016 \\
\hline Orange Polska (wcześniej PTK Centertel) & 29,2 & 27,6 & 26,9 & 26,7 & 27,7 & 28,2 \\
Polkomtel & 27,9 & 25,6 & 24,8 & 22,6 & 22,6 & 22,1 \\
T-Mobile Polska (wcześniej PTC) & 27,7 & 29,3 & 27,0 & 26,8 & 20,8 & 18,6 \\
P4 & 14,1 & 16,1 & 18,8 & 21,9 & 25,8 & 27,1 \\
pozostali & 1,0 & 0,2 & 2,5 & 2,0 & 3,1 & 4,1 \\
\hline
\end{tabular}

Źródło: Opracowanie własne na podstawie UKE (2012a-2017a).

Tabela 5.

Udział operatorów pod względem przychodów rynku telefonii ruchomej w Polsce w latach 2011-2016 (w\%)

\begin{tabular}{lrrrrrr}
\hline \multicolumn{1}{c}{ Operator } & 2011 & 2012 & 2013 & 2014 & 2015 & 2016 \\
\hline Orange Polska (wcześniej PTK Centertel) & 31,6 & 30,7 & 29,3 & 28,3 & 26,7 & 25,7 \\
Polkomtel & 30,7 & 30,4 & 30,2 & 29,3 & 27,9 & 26,8 \\
T-Mobile Polska (wcześniej PTC) & 28,4 & 26,1 & 24,5 & 22,4 & 21,2 & 19,9 \\
P4 & 9,1 & 12,5 & 15,5 & 19,8 & 23,6 & 25,4 \\
pozostali & 0,3 & 0,3 & 0,4 & 0,2 & 0,7 & 2,3 \\
\hline
\end{tabular}

Źródło: Opracowanie własne na podstawie UKE (2012a-2017a).

Tabela 6.

Bilans przenośności numerów na rynku telefonii ruchomej w Polsce w latach 2011-2016 (w tys.)

\begin{tabular}{lrrrrrr}
\hline \multicolumn{1}{c}{ Operator } & 2011 & 2012 & 2013 & 2014 & 2015 & 2016 \\
\hline Orange Polska (wcześniej PTK Centertel) & $-209,0$ & $-248,0$ & $-134,9$ & $-47,1$ & $-35,3$ & $-128,6$ \\
Polkomtel & $-233,0$ & $-261,9$ & $-290,2$ & $-298,9$ & $-156,6$ & $-100,9$ \\
T-Mobile Polska (wcześniej PTC) & $-281,0$ & $-217,3$ & $-326,6$ & $-236,7$ & $-314,0$ & 0,5 \\
P4 & 721,0 & 731,3 & 761,1 & 590,5 & 442,1 & 111,3 \\
pozostali & 2,0 & $-4,1$ & $-9,7$ & $-7,8$ & 63,7 & 117,8 \\
\hline
\end{tabular}

Źródło: Opracowanie własne na podstawie danych Telepolis (2012-2017).

Tabela 7 .

Udział operatorów w ogólnej liczbie użytkowników Internetu w Polsce w latach 2011-2016 (w \%)

\begin{tabular}{lrrrrrr}
\hline \multicolumn{1}{c}{ Operator } & 2011 & 2012 & 2013 & 2014 & 2015 & 2016 \\
\hline Orange Polska (wcześniej TP SA i PTK Centertel oddzielnie) & 36,0 & 36,7 & 31,8 & 29,1 & 30,0 & 32,2 \\
Polkomtel & 10,4 & 9,7 & 8,3 & 8,8 & 9,2 & 8,9 \\
T-Mobile Polska (wcześniej PTC) & 6,7 & 7,4 & 9,5 & 8,3 & 7,6 & 6,9 \\
P4 & 7,5 & 7,8 & 8,4 & 7,0 & 7,6 & 7,2 \\
UPC & 6,0 & 7,4 & 8,5 & 7,6 & 7,5 & 7,7 \\
Netia & 4,4 & 3,5 & 4,0 & 4,4 & 4,1 & 3,6 \\
Multimedia Polska & 3,6 & 3,4 & 3,8 & 3,4 & 3,2 & 4,0 \\
pozostali & 25,4 & 24,1 & 25,7 & 31,4 & 30,8 & 29,5 \\
\hline
\end{tabular}

Źródło: Opracowanie własne na podstawie UKE (2012a-2016a). 
Tabela 8.

Udział operatorów w ogólnej liczbie użytkowników Internetu stacjonarnego w Polsce w latach 2011-2015 $(\mathrm{w} \%)$

\begin{tabular}{|c|c|c|c|c|c|}
\hline Operator & 2011 & 2012 & 2013 & 2014 & 2015 \\
\hline Orange Polska (wcześniej TP SA i PTK Centertel oddzielnie) & 42,3 & 42,9 & 34,9 & 31,5 & 29,9 \\
\hline UPC & 8,9 & 11,3 & 14,0 & 13,8 & 14,6 \\
\hline Netia & 4,4 & 5,3 & 6,2 & 7,9 & 7,7 \\
\hline Vectra & 5,0 & 5,1 & 6,5 & 6,8 & 7,3 \\
\hline Multimedia Polska & 5,0 & 4,7 & 5,9 & 5,7 & 5,8 \\
\hline Telefonia Dialog & 2,2 & 1,9 & 1,6 & 1,6 & 1,4 \\
\hline Internetia & 1,5 & 1,5 & 1,7 & 1,5 & 1,4 \\
\hline Inea & 1,1 & 1,1 & 1,7 & 1,7 & 2,2 \\
\hline pozostali & 29,6 & 26,2 & 27,5 & 29,5 & 29,7 \\
\hline
\end{tabular}

Uwagi:

Ze względu na brak danych pominięto 2016 rok.

Źródło: Opracowanie własne na podstawie UKE (2012a-2016a).

\section{Wykres 1.}

Wartość branży telekomunikacyjnej w Polsce w latach 2011-2016 (w mld PLN)

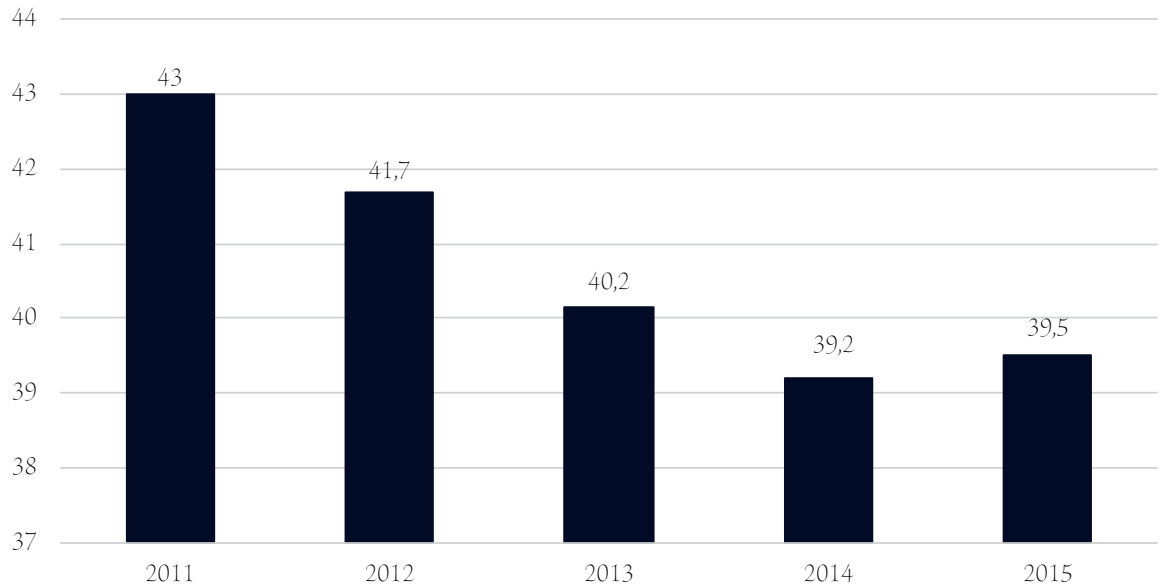

Źródło: Opracowanie własne na podstawie UKE (2012a-2017a). 
Wykres 2.

Liczba abonentów telefonii stacjonarnej w Polsce w latach 2011-2016 ( $\mathrm{w}$ mln)

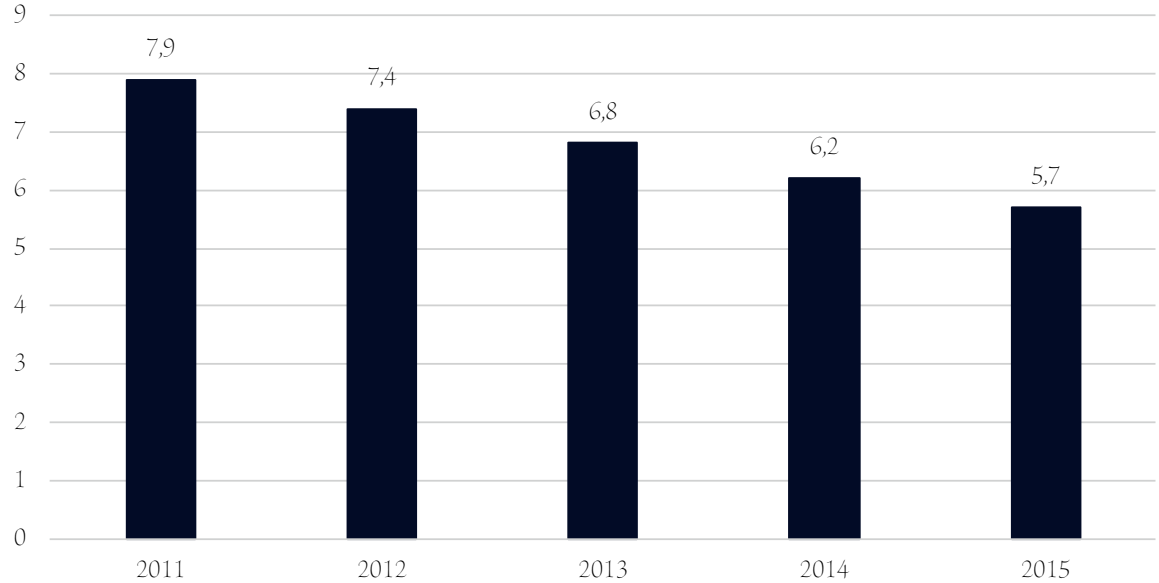

Źródło: Opracowanie własne na podstawie UKE (2012a-2017a).

Wykres 3.

Średni, miesięczny przychód z abonenta telefonii stacjonarnej w Polsce w latach 2011-2016 (w PLN)

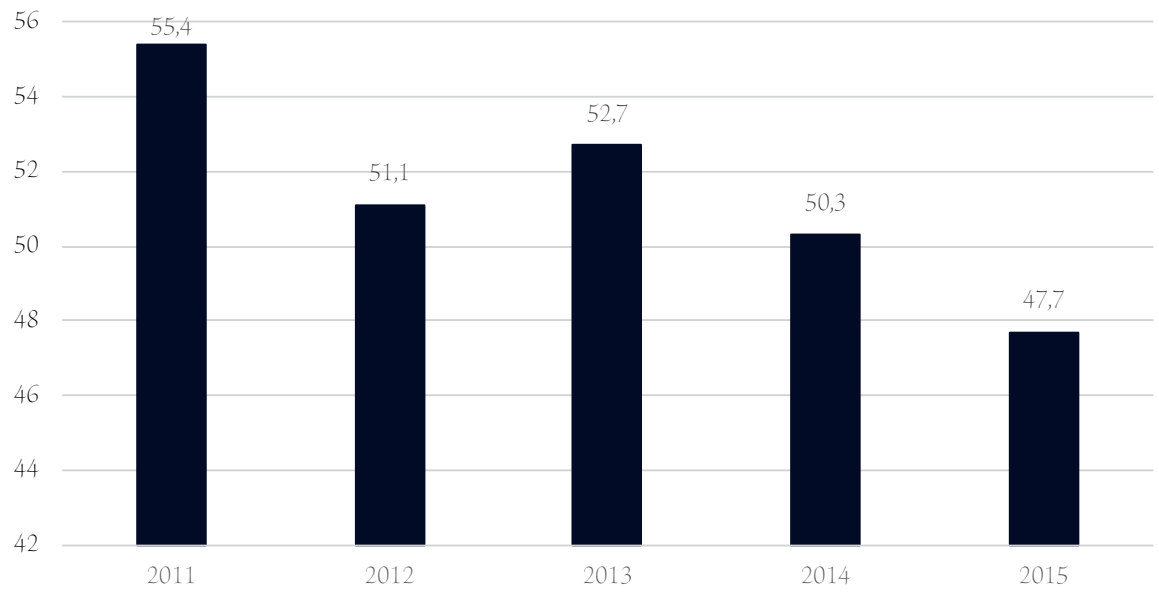

Źródło: Opracowanie własne na podstawie UKE (2012a-2017a). 
Wykres 4.

Wartość rynku telefonii stacjonarnej w Polsce w latach 2011-2016 (w mld PLN)

6

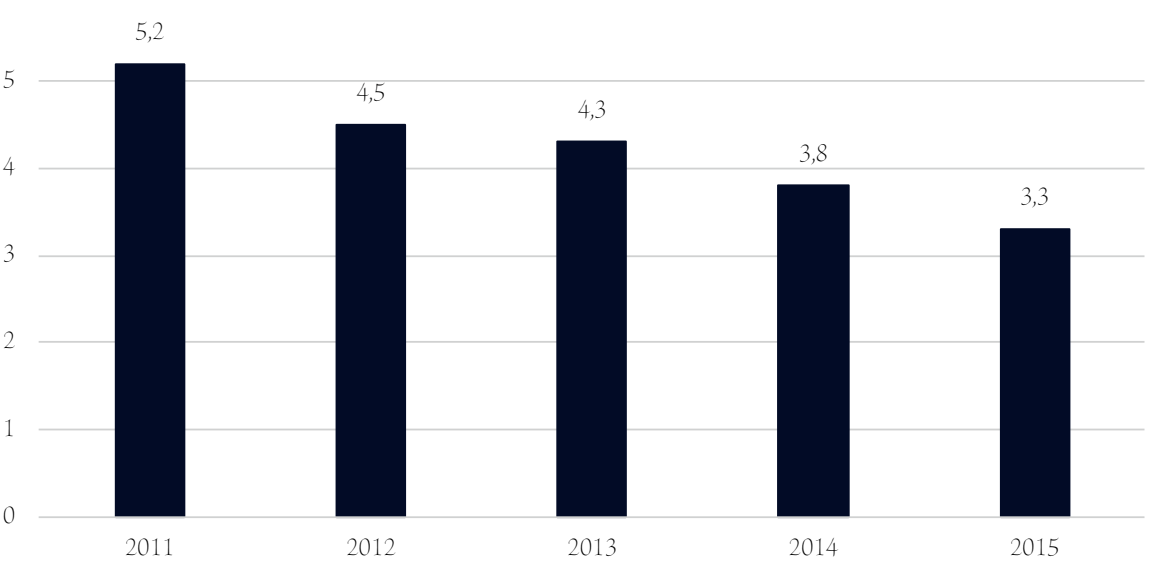

Żródło: Opracowanie własne na podstawie UKE (2012a-2017a).

Wykres 5.

Nominalna liczba użytkowników rynku telefonii ruchomej w Polsce w latach 2011-2016 (w mln) 60

57,8

58
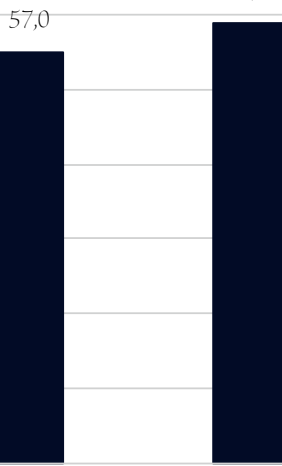

56,6

56

53,9

54

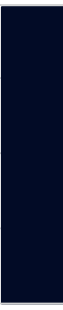

2011

2012

2013

2014

2015

Źródło: Opracowanie własne na podstawie UKE (2012a-2017a). 
Wykres 6.

Wskaźnik nasycenia rynku telefonii ruchomej w Polsce w latach 2011-2016 (w \%)

155

150

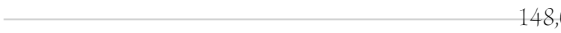

150,2

145

140,0

140

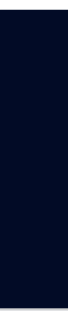

2012
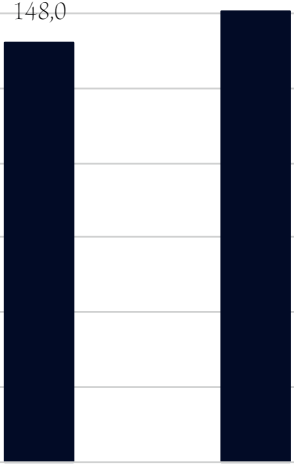

147,2

135

131,6

130

125

120
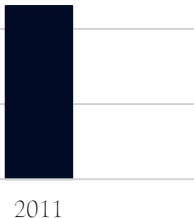

2013

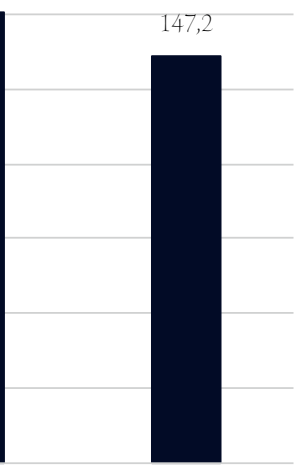

2014

2015

Żródło: Opracowanie własne na podstawie UKE (2012a-2017a).

Wykres 7.

Średni, miesięczny przychód z abonenta telefonii mobilnej w Polsce w latach 2011-2015 (w PLN)

35

31,6

30

29,2

25

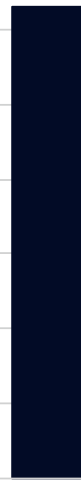

(2)

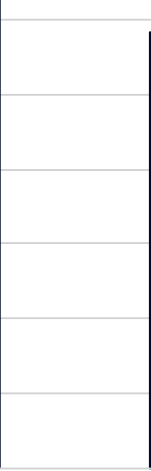

$$
2011
$$

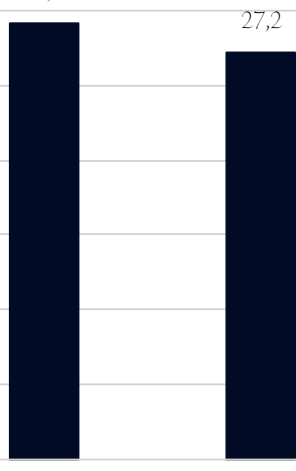

2012

2013

25,4

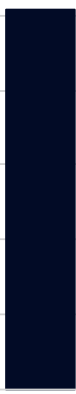

2014
25,3

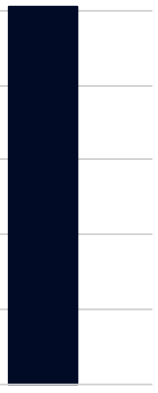

2015

Uwagi:

Ze względu na brak danych pominięto 2016 rok.

Źródło: Opracowanie własne na podstawie UKE (2012a-2016a). 
Wykres 8.

Wartość rynku telefonii ruchomej w Polsce w latach 2011-2016 (w mld PLN)

19,5

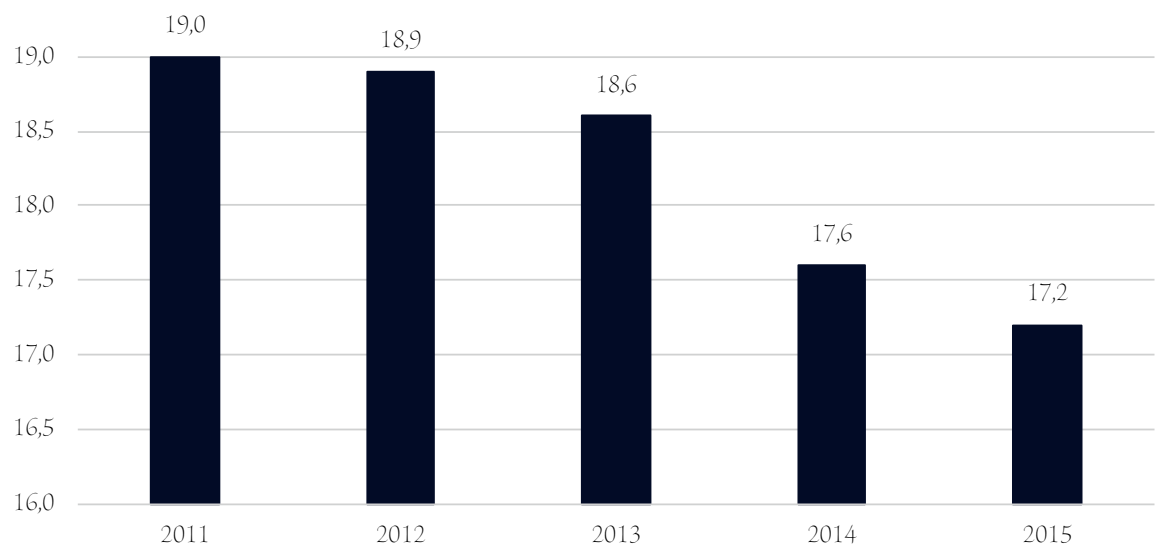

Źródło: Opracowanie własne na podstawie UKE (2012a-2017a).

Wykres 9.

Wskaźniki nasycenia Internetem szerokopasmowym w Polsce w latach 2011-2016 (w \%)

120

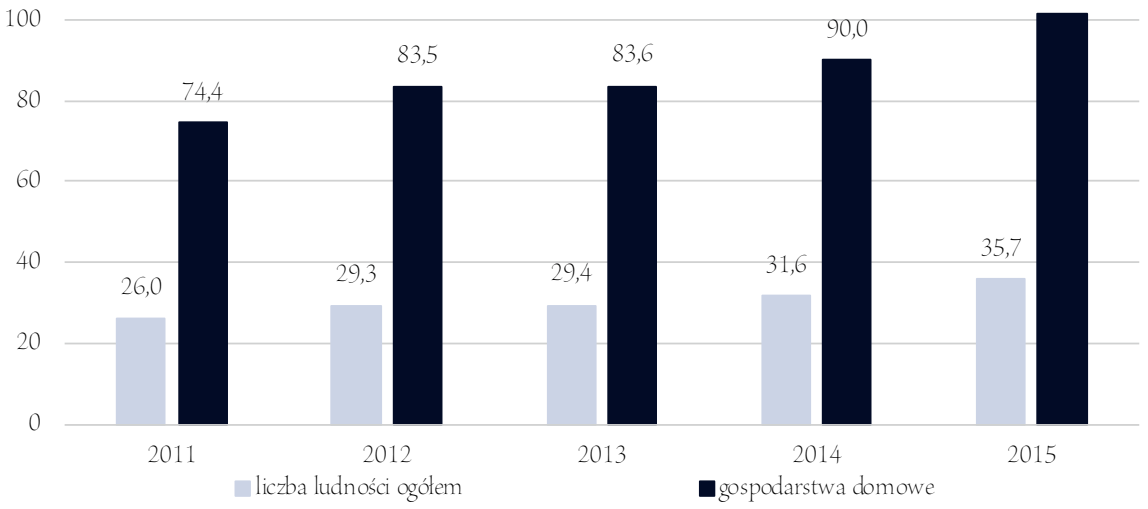

Źródło: Opracowanie własne na podstawie UKE (2012a-2017a). 
Wykres 10.

Średni, miesięczny przychód z abonenta rynku dostępu do Internetu w Polsce w latach 2011-2016 (w PLN) 36

35,1

35

34

33

32

31

30

29

28

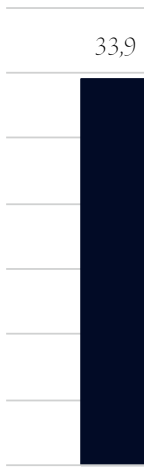

2011
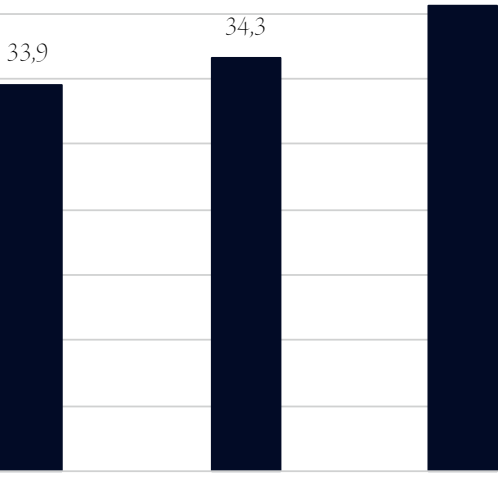

2012

32,9

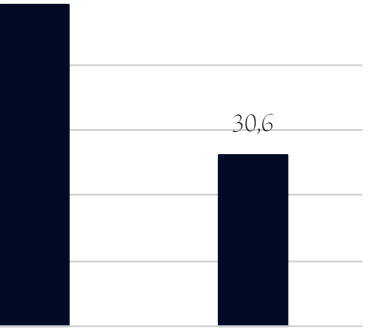

2014

2015

Źródło: Opracowanie własne na podstawie UKE (2012a-2017a).

Wykres 11.

Wartość rynku dostępu do Internetu w Polsce w latach 2011-2016 (w mld PLN)

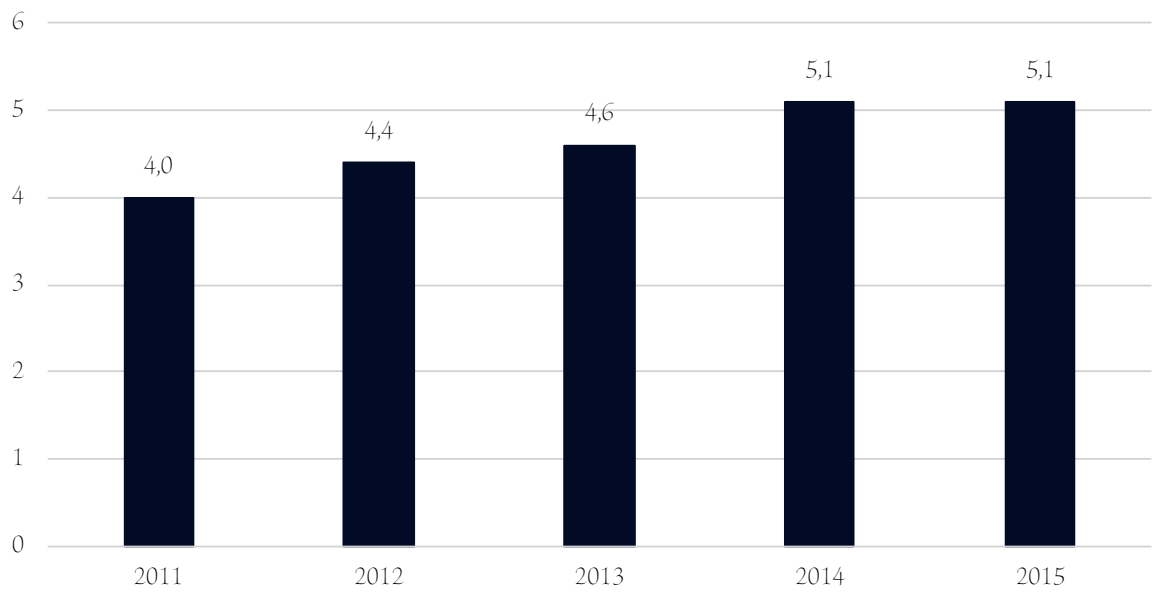

Źródło: Opracowanie własne na podstawie UKE (2012a-2017a). 
Wykres 12 .

Liczba abonentów usług wiązanych w Polsce w latach 2011-2016 (w mln)

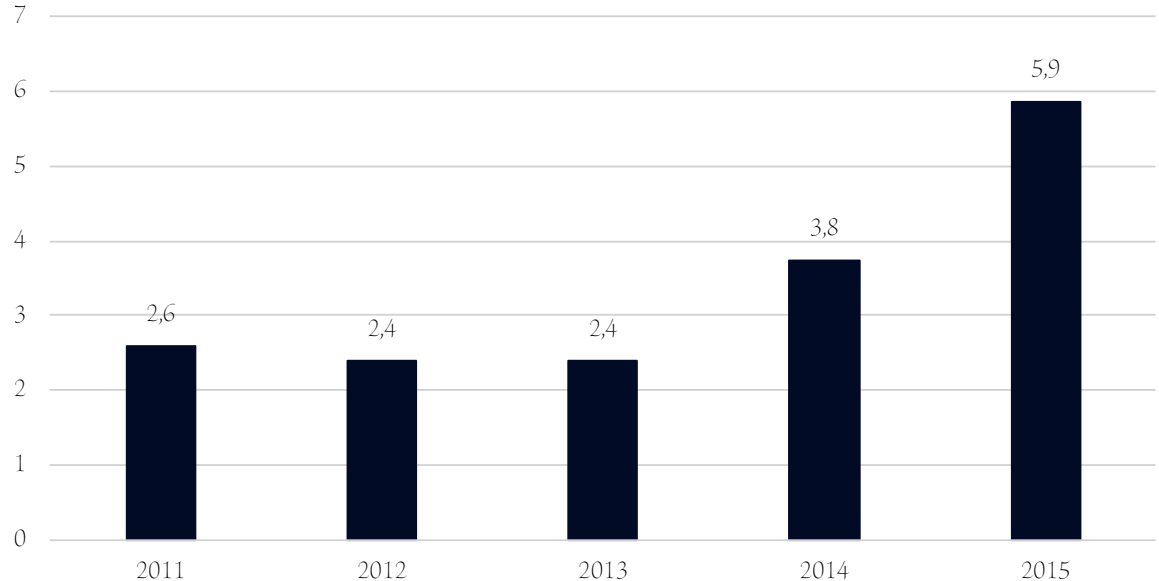

Żródło: Opracowanie własne na podstawie UKE (2012a-2017a).

Wykres 13.

Udział operatorów w ogólnej liczbie abonentów najpopularniejszego pakietu telewizja + Internet stacjonarny w Polsce w latach 2011-2013 (w\%)

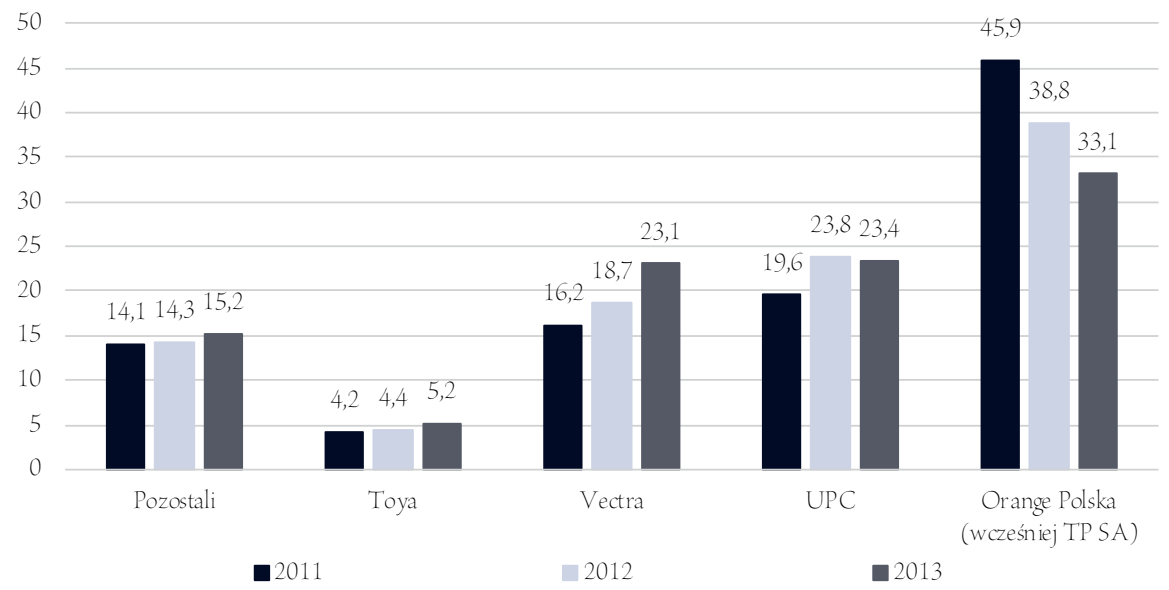

Uwagi:

Ze względu na brak danych pominięto lata 2014-2016.

Źródło: Opracowanie własne na podstawie UKE (2012a-2015a). 


\section{Wykres 14}

\section{Udział operatorów w ogólnej liczbie użytkowników usług wiązanych w Polsce w latach 2014-2016 (w \%)}

\section{5}

30,1

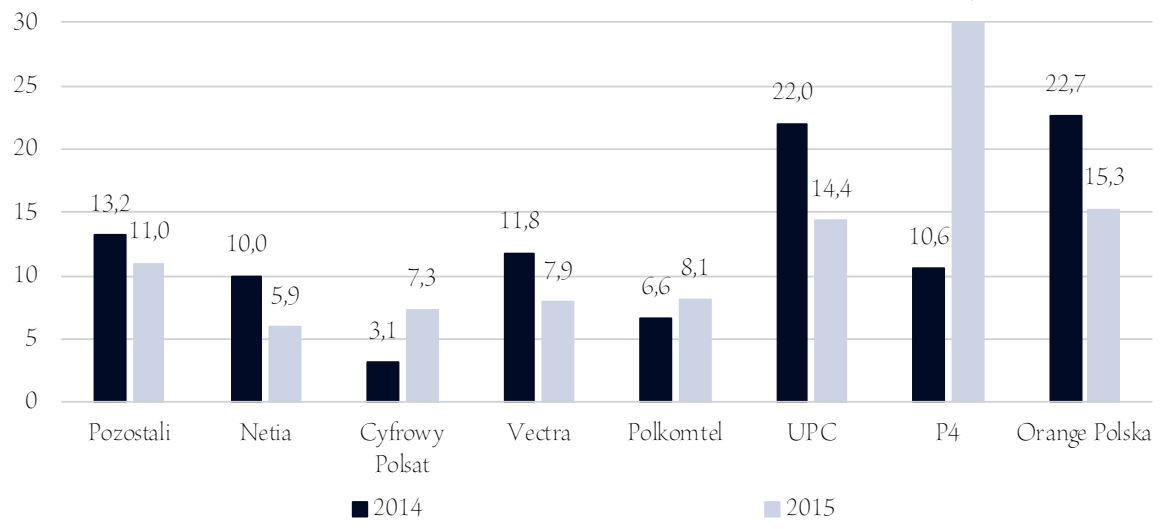

Uwagi:

Ze względu na brak danych pominięto lata 2011-2013.

Źródło: Opracowanie własne na podstawie UKE (2015a-2017a).

Privatization process of the telecommunications industry in Poland and the competitive position of the Orange Group

\footnotetext{
Abstract

Motivation: The telecommunications industry in Poland for many years was legally monopolized by a single, stateowned operator, Telekomunikacja Polska SA (hereinafter TP SA). In 1998, however, a long process of privatization of the company began, which was accompanied by the liberalization of the telecommunications industry. The services have become increasingly cheaper for consumers, who has started to use convergence offerings, as well as the new telecommunications technologies have developed rapidly. A start-up of new operators significantly weakened the competitive position of the former telecommunications industry monopolist. In the literature of the subject there is no interpretation of the deep transformations taking place in the telecommunications industry. The assessment of these transformations in terms of the competitive position of the Orange Polska Capital Group (hereinafter Orange Group) is a key motive for the selection of the article subject.

Aim: The aim of this article is to demonstrate the relationship between the privatization of TP SA and the competitive position of the Orange Group. The research was conducted through statistical data evaluation. The analysis was based on the report of the Office of Electronic Communications (UKE) about the state of the telecommunications industry in Poland.

Results: The analysis showed the relationship between TP SA privatization process and the competitive position of Orange Group. As a result of these changes, the Orange Group has lost part of its share in each segment of the telecommunications market in Poland.

Keywords: privatization of TP SA; liberalization of the telecommunications industry; competitive position; Orange Polska Capital Group JEL: DOO; GOO; B52
} 